\title{
THERMAL ECOLOGY AND ACTIVITY PATTERNS OF THE LIZARD COMMUNITY OF THE RESTINGA OF JURUBATIBA, MACAÉ, RJ
}

\author{
HATANO, F. H., VRCIBRADIC, D., GALDINO, C. A. B., CUNHA-BARROS, M., \\ ROCHA, C. F. D. and VAN SLUYS, M. \\ Setor de Ecologia, Ibrag, Universidade do Estado do Rio de Janeiro, Rua São Francisco Xavier, 524, \\ Maracanã, CEP 20550-011, Rio de Janeiro, RJ, Brazil \\ Correspondence to: Carlos Frederico D. Rocha, Setor de Ecologia, Ibrag, Universidade do Estado do Rio de Janeiro, Rua \\ São Francisco Xavier, 524, Maracanã, CEP 20550-011, Rio de Janeiro, RJ, Brazil, e-mail: cfdrocha@uerj.br \\ Received March 9, 2000 - Accepted April 13, 2000 - Distributed May 31, 2001
}

(With 2 figures)

\begin{abstract}
We analyzed the thermal ecology and activity patterns of the lizard community from the Restinga of Jurubatiba, Rio de Janeiro, Brazil. The broadest activity was that of Tropidurus torquatus, a sit-andwait forager, while the active foraging teiid Cnemidophorus littoralis had the shortest activity. The nocturnal gekkonid Hemidactylus mabouia was found active during the day only during early morning and late afternoon, when environmental temperatures are low. Body temperature was highest for Cnemidophorus littoralis and lowest for the two Mabuya species. The patterns found here are discussed and compared to those of congeneric species in other habitats in Brazil.
\end{abstract}

Key words: thermal ecology, lizard community, activity patterns, restinga habitat.

\section{RESUMO}

\section{Ecologia termal e padrões de atividade da comunidade de lagartos da restinga de Jurubatiba, Macaé, RJ}

Foram analizados a ecologia termal e os padrões de atividade da comunidade de lagartos da restinga de Jurubatiba, Rio de Janeiro, Brasil. A espécie com atividade mais extensa foi Tropidurus torquatus, um forrageador "senta-e-espera", enquanto o forrageador ativo Cnemidophorus littoralis teve a atividade mais restrita. O geconídeo noturno Hemidactylus mabouia foi encontrado ativo durante o dia apenas no início da manhã e no final da tarde, quando as temperaturas ambientais estão baixas. A temperatura corpórea foi mais alta para Cnemidophorus littoralis e mais baixa para as duas espécies de Mabuya. Os padrões aqui encontrados são discutidos e comparados com os de espécies congenéricas em outros habitats no Brasil.

Palavras-chave: ecologia termal, comunidade de lagartos, padrões de atividade, restinga.

\section{INTRODUCTION}

Differentiation in the use of the time niche by different species of lizards within a community has been indicated as an important factor minimizing competition among sympatric lizards species (e.g. Pianka, 1973). The body temperatures of active individuals often reflect the time of activity and the intensity of foraging reasonably well (e.g. Pianka,
1973; Bergallo \& Rocha, 1993). The species which initiates activity earlier in the day and remains active over longer periods of time often have lower and more variable body temperatures than species with narrower activity periods (Pianka, 1977; Pianka $e t$ al., 1979). Foraging behavior is also correlated with activity temperature: active foragers, in general, tend to have higher mean body temperatures than sedentary predators (e.g. Bowker, 1984; Bowker 
et al., 1986; Colli \& Paiva, 1997). In the restinga of Jurubatiba, in Rio de Janeiro State, Brazil (see below), at least eight lizard species may be found sympatrically, four of them being relatively common (i.e. the tropidurid Tropidurus torquatus, the teiid Cnemidophorus littoralis, and the scincids Mabuya agilis and M. macrorhyncha). These species have been shown to differ in foraging intensity in other areas where they have been studied (Bergallo \& Rocha, 1994; Teixeira-Filho et al., 1995; Vrcibradic \& Rocha, 1996) and are expected to differ consistently in activity patterns and active body temperatures in the restinga of Jurubatiba.

In the present study we analyse the activity patterns and body temperatures of the most abundant lizard species in the study area, and specifically address the following questions: $i$ ) To which extent do the lizards of the community under study differ in activity period and body temperature in activity? ii) Do the mean body temperature differ among the sexes within species?

\section{MATERIALS AND METHODS}

\section{Study area}

The study was carried out in the restinga of Jurubatiba, in Rio de Janeiro State, Brazil, more precisely at an area adjacent to the Cabiúnas lagoon ( $\left.22^{\circ} 16^{\prime} \mathrm{S} ; 41^{\circ} 41^{\prime} \mathrm{W}\right)$, corresponding to the open Clusia formation (sensu Henriques et al., 1986). The 'restingas' are coastal sand dune habitats covered with herbaceous and shrubby vegetation, common along the Brazilian coast (Suguio \& Tessler, 1984). Annual rainfall in the area averages $1,164 \mathrm{~mm}$, and is markedly seasonal, with mean monthly totals ranging from $41 \mathrm{~mm}$ during the winter to $189 \mathrm{~mm}$ during the summer (Henriques et al., 1986). Mean monthly temperature varies from $29.7^{\circ} \mathrm{C}$ in January to $20.0^{\circ} \mathrm{C}$ in July, with annual average of $22.6^{\circ} \mathrm{C}$ (Henriques et al., 1986). For a comprehensive description of the vegetation of the area see Henriques et al. (1986) and Araújo et al. (1998).

\section{Methodology}

Field work was carried out during March 1999. We also utilized temperature data from Mabuya spp. collected on earlier visits to the area (i.e. on April 1997 and on January, September,
October and December 1998), to increase sample sizes for those species. Data gathering for activity patterns included both visual observations and collecting (data for the large teiid T. merianae included only visual records). Visual observations were carried out during diurnal transects which consisted of a well demarcated path (evidenced by a trail approximately $500 \mathrm{~m}$ in extent in the sand and bright orange tapes tied to the vegetation and spaced $10 \mathrm{~m}$ from one another), along which observations were made by a pair of observers from 6:00 h to $19: 00 \mathrm{~h}$ at hourly intervals during three days. Air temperature was taken at each hourly interval, prior to initiating the corresponding transect. Each transect lasted approximately 30 min, and all lizards seen during each transect were recorded and categorized according to their species.

Collections for body temperature measurements were done using air rifles, rubber bands, and a noose, in a sub-area different (but physionomically indistinguishable) from that we used for activity estimates. Lizards that were not killed instantly were transferred to a plastic bag and killed with ether. For each lizard collected, we recorded the time of capture, as well as cloacal, air $(1 \mathrm{~cm}$ above original location of the lizard) and substrate (i.e. soil) temperatures. Temperatures were taken with quick-reading cloacal thermometers (shaded bulb) to the nearest $0.2^{\circ} \mathrm{C}$, and lizard cloacal temperatures were always recorded within $30 \mathrm{sec}$. of capture. The lizards collected were fixed in $10 \%$ formalin and placed in $70 \%$ alcohol. The collecting site and the transect site were ca. $100 \mathrm{~m}$ apart.

Regression analysis was used to test for the relationship between mean body temperature and air temperature and substrate temperature for each lizard species. Differences in mean body temperatures among species and between sexes, for each species, were tested using t-tests (Zar, 1984).

\section{RESULTS}

We found six lizard species in the restinga of Jurubatiba for which we recorded activity data: Cnemidophorus littoralis and Tupinambis merianae (Teiidae), Hemidactylus mabouia (Gekkonidae), Mabuya agilis and M. macrorhyncha (Scincidae), and Tropidurus torquatus (Tropiduridae). The gekkonid Gymnodactylus darwini and the teiid Ameiva ameiva also occur at the area, but no acti- 
vity data could be taken for the former due to its reclusive habits and for the latter due to its low abundance in the area.

Periods of activity varied among species (Fig. 1). Tropidurus torquatus was active along all day but with a bimodal activity pattern, and the other species had more restricted and unimodal patterns of activity (Fig. 1). The decrease in activity of $T$. torquatus and the peak activity of $C$. littoralis coincided with the period of highest environmental temperatures (Fig. 1). Mabuya macrorhyncha was mostly active during the morning, when air temperature is rising gradually (Fig. 1). The predominantly nocturnal gekkonid $H$. mabouia was observed active during the periods 07:00-08:00 (N $=3$ ) and 16:00-17:00 ( $\mathrm{N}=1)$ (Fig. 2), basking in the mild sun perched on bromeliad leaves. Activity of $T$. merianae and $M$. agilis were concentrated around midday and early afternoon and on mid- to late afternoon, respectively (Fig. 2).

Field body temperatures of active lizards were taken from all species except $H$. mabouia and $T$. merianae; those species were only observed, but could not be collected.

The mean body temperature of active Tropidurus torquatus was $34.8 \pm 2.4^{\circ} \mathrm{C}(\mathrm{N}=42)$, with a range of $28.6-39.0^{\circ} \mathrm{C}$. Males and females did not differ significantly in their mean body temperature (t-test; $\mathrm{t}=0.38, \mathrm{DF}=39, \mathrm{p}=0.71$ ). The body temperature of $T$. torquatus was significantly related to air temperature $\left(\mathrm{R}^{2}=0.44, \mathrm{p}<0.001, \mathrm{~N}=42\right)$ and to substrate temperature $\left(\mathrm{R}^{2}=0.30, \mathrm{p}<0.001\right.$, $\mathrm{N}=38$ ).

Cnemidophorus littoralis had a mean body temperature of $38.6 \pm 2.2^{\circ} \mathrm{C}(\mathrm{N}=21)$, with a range of $30.2-41.0^{\circ} \mathrm{C}$. Males and females did not differ significantly in their mean body temperature (t-test; $\mathrm{t}=1.54, \mathrm{DF}=18, \mathrm{p}=0.14)$. The body temperature of $C$. littoralis was not significantly related to either air temperature $\left(\mathrm{R}^{2}=0.07, \mathrm{p}=0.25, \mathrm{~N}=21\right)$ or substrate temperature $\left(\mathrm{R}^{2}=0.003, \mathrm{p}=0.74, \mathrm{~N}=\right.$ 20).

Mabuya macrorhyncha had a mean body temperature of $32.7 \pm 2.7^{\circ} \mathrm{C}(\mathrm{N}=24)$ varying from $27.6^{\circ} \mathrm{C}$ to $37.0^{\circ} \mathrm{C}$. The mean body temperature differed significantly between the sexes (t-test; $\mathrm{t}=$ $2.09, \mathrm{DF}=22, \mathrm{p}=0.048)$, being higher for females $\left(33.8 \pm 2.1^{\circ} \mathrm{C}, \mathrm{N}=12\right)$ than for males $(31.7 \pm$ $3.0^{\circ} \mathrm{C}, \mathrm{N}=12$ ). Body temperature was significantly related to air temperature $\left(\mathrm{R}^{2}=0.60, \mathrm{p}<0.001\right.$,
$\mathrm{N}=24$ ). We did not correlate body temperature with substrate temperature for this species due to scarcity of data, since most specimens were perched above ground.

The mean body temperature of Mabuya agilis was $33.3 \pm 3.2^{\circ} \mathrm{C}(\mathrm{N}=6)$, and varied from 29.6 to $37.2^{\circ} \mathrm{C}$. The sample size of this species was too small to test for sexual differences and for relationships between cloacal and environmental temperatures.

The mean body temperature differed significantly between the two most abundant lizard species, T. torquatus and C. littoralis (t-test; $\mathrm{t}=$ $6.40, \mathrm{DF}=36, \mathrm{p}<0.001)$. Body temperatures did not differ between the two Mabuya species (t-test; $\mathrm{t}=4.08, \mathrm{DF}=28, \mathrm{p}=0.69)$. The body temperatures of Mabuya spp. (pooled values for both species) was significantly lower than those of $C$. littoralis ( $\mathrm{t}$-test; $\mathrm{t}=6.67, \mathrm{DF}=36, \mathrm{p}<0.001$ ) and T. torquatus $(\mathrm{t}$-test; $\mathrm{t}=-2.58, \mathrm{DF}=36, \mathrm{p}<0.05)$.

\section{DISCUSSION}

All species recorded in the area are diurnal, except the gekkonid Hemidactylus mabouia, which is predominantly nocturnal. Most activity, for all species, occurred from early morning to early afternoon. The species with the broadest activity period was $T$. torquatus, which began activity shortly after sunrise and remained active until after sunset. Similarly, extended activities have been previously reported for this species at the restingas of Barra de Maricá (Araújo, 1984; Teixeira-Filho et al., 1996) and Linhares (Bergallo \& Rocha, 1993) and for other congeners in different open habitats in Brazil (Van Sluys, 1992; Vitt et al., 1996; Vitt \& Zani, 1998). Other populations of open-habitat congeners have somewhat shorter activity periods (Vitt, 1993, 1995; Vitt \& Carvalho, 1995), apparently due to characteristics of their particular habitats, related mainly to the proportional availability of direct sunlight along the day. The characteristics of the restinga habitat, with its low canopy and sparse vegetation, provides sunlit conditions throughout the day, which probably allows the heliophillous $T$. torquatus to exploit the diurnal temporal niche to its full extent in such areas (Rocha \& Bergallo, 1997, have shown that the abundance of lizards in restinga habitats is mainly influenced by the rate of insulation on the ground). 

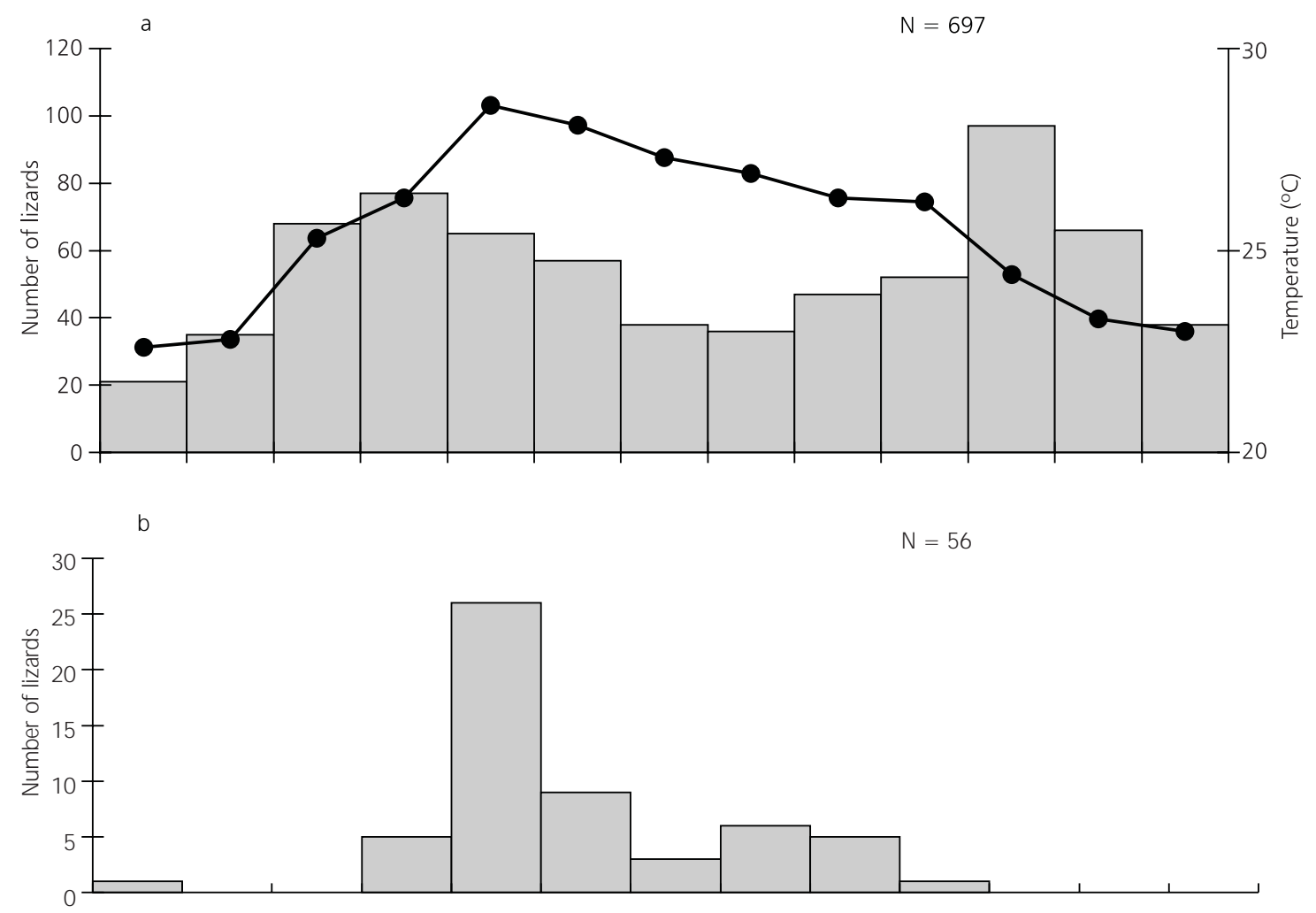

C

$N=11$

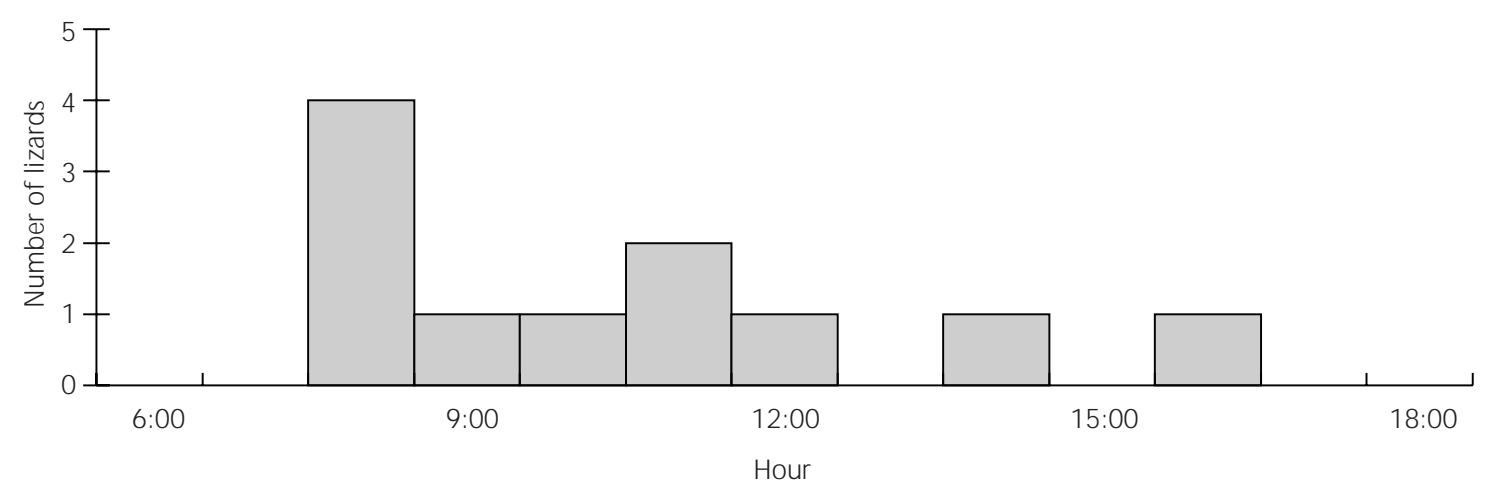

Fig. 1 - (a) air temperature (in ${ }^{\circ} \mathrm{C},--$-) and number of active Tropidurus torquatus $(\mathrm{N}=697$; bars); (b) number of active Cnemidophorus littoralis $(\mathrm{N}=56)$; and (c) number of active Mabuya macrorhyncha $(\mathrm{N}=11)$, recorded at the transects during March 1999, at the restinga of Jurubatiba, Macaé, RJ.

The bimodal pattern of wet-season activity of T. torquatus observed at Jurubatiba, with peaks at mid-morning and mid-afternoon and a decrease in activity around midday, when environmental temperatures are higher, has been observed for this species at Barra de Maricá (Araújo, 1984) and for other Brazilian congeners in different open habitats (Van Sluys, 1992; Vitt, 1993; Vitt \& Carvalho, 1995). Reduction of activity at the hottest periods of the day is probably a means of avoiding extreme environmental temperatures (in restingas, the temperature of the exposed sand may reach $60^{\circ} \mathrm{C}$ during such periods). 
The activity of $C$. littoralis was unimodal and relatively restricted compared to that of the tropidurid, being concentrated in the morning and decreasing considerably after midday. A similar activity pattern has been observed for this species at Barra de Maricá (Araújo, 1984) and for other Brazilian congeners (C. ocellifer at the 'cerrado' of central Brazil - Vitt, $1991-$, C. nativo at the restinga of Linhares - Bergallo \& Rocha, 1993 -, C. lemniscatus in open habitats within the Amazonian biome - Vitt \& Carvalho, 1995; Vitt et al., 1997a), though a population of $C$. ocellifer at the 'caatinga' of northeast Brazil apparently has a more extended activity (Vitt, 1995).
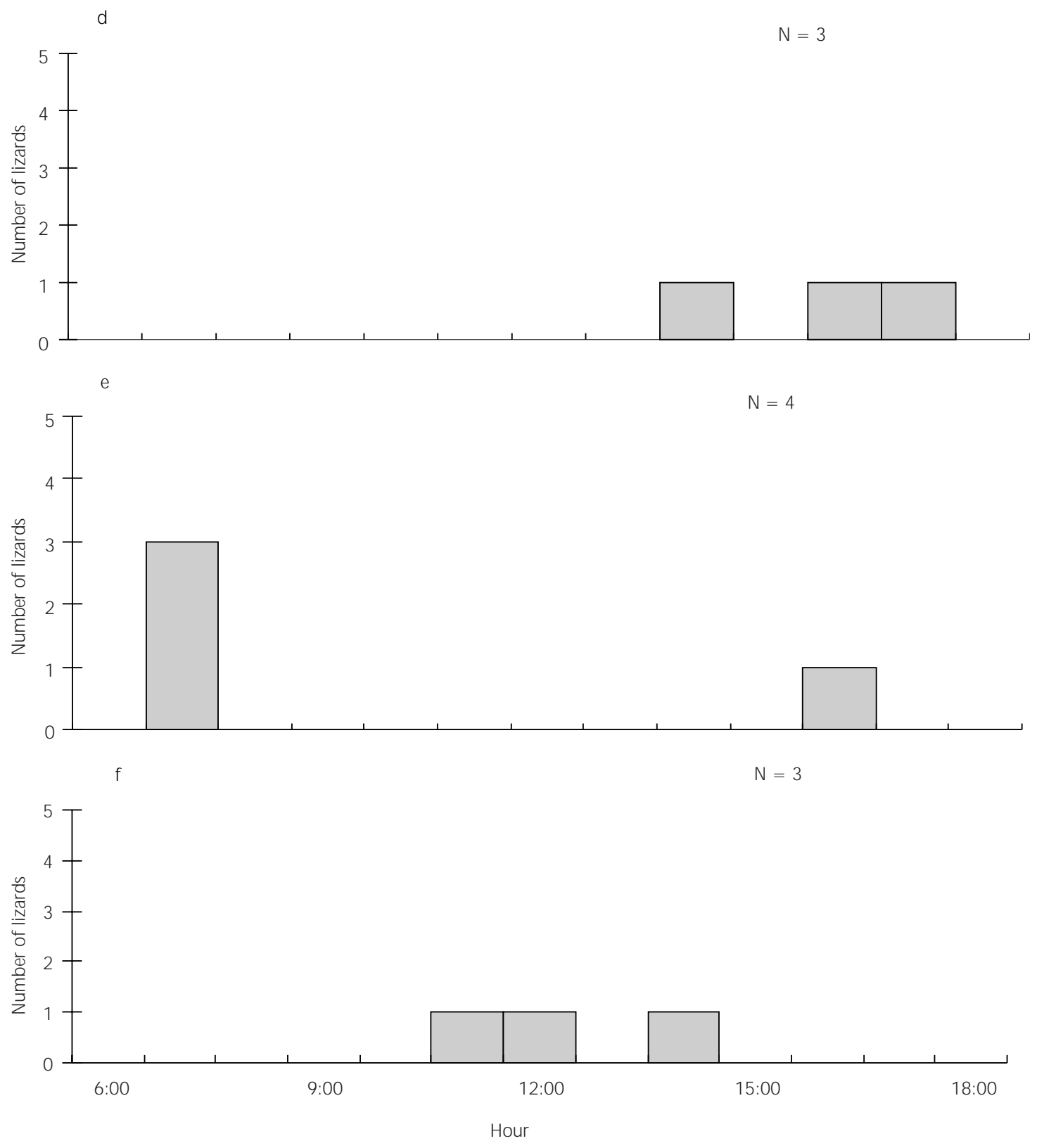

Fig. 2 - (d) number of active Mabuya agilis ( $\mathrm{N}=3$ ); (e) number of active Hemidactylus mabouia $(\mathrm{N}=4)$; and (f) number of active Tupinambis merianae $(\mathrm{N}=3$ ), recorded at the transects during March 1999, at the restinga of Jurubatiba, Macaé, RJ. 
The activity pattern of $C$. littoralis at Jurubatiba was somehow inverse to that of $T$. torquatus, with the peak of activity coinciding with the raising in ambient temperature. This observation agrees with the higher thermal requirements of this teiid compared to T. torquatus (see below). A study of Bergallo \& Rocha (1993) also evidenced a more restricted activity for $C$. nativo (8:30 to $15: 00 \mathrm{~h}$ ) compared to the sympatric $T$. torquatus (7:00 to 18:00 h) in Linhares, but that study was conducted during the dry season (winter) and the activity pattern was unimodal for both species.

Although data for the two Mabuya species were limited, they suggest that these skinks remain active until later in the day than $C$. littoralis. This may reflect their lower thermal requirements compared to the teiid. These two scincid species are known to have a relatively wide activity period in other restinga areas of South-eastern Brazil (Vrcibradic \& Rocha, 1995, 1996).

Data for the gekkonid H. mabouia and for the teiid T. merianae were scant, but nevertheless suggest that the former is diurnally active mainly during the early morning and late afternoon, when temperatures and insolation are mild, and that the latter is active during the hottest hours of the day. Data for T. merianae at the Brazilian caatinga (Vitt, 1995) and at an Atlantic rainforest area (Van Sluys \& Rocha, 1999), and for populations of its congener T. teguixin (Vitt \& Carvalho, 1995; Vitt \& Zani, 1998) have also indicated a peak of activity during midday and early afternoon, as observed in Jurubatiba. Being active mainly during the hotter hours of the day is probably important for these large teiids to maximize their heat gain to meet their high thermal requirements; a large lizard is supposed to take relatively long to warm up, and the longer it stays exposed to the sun, the greater is also its risk of exposure to visually oriented predators (see Martín \& López, 1996). Hemidactylus mabouia, though primarily nocturnal (e.g. Vitt, 1995), can be active during the day, but usually during periods when ambient temperatures are relatively low.

Body temperatures of the four most abundant species differed significantly among genera (or, rather, among families), with the teiid $C$. littoralis having the highest values, the two scincids having the lowest ones and the tropidurid T. torquatus being intermediate. The mean body temperatures of $T$. torquatus and C. littoralis at our study area were almost equal to those of the respective conspecific populations of Maricá (Teixeira-Filho et al., 1995, 1996). The body temperatures of the two Mabuya species were also similar to those of conspecific populations of Maricá (Rocha \& Vrcibradic, 1996), and to those of other Brazilian congeners (Vitt et al., 1997b; Vrcibradic \& Rocha, 1998). The difference in mean body temperature between male and female $M$. macrorhyncha is difficult to explain, since no such difference has been observed in a conspecific population at Barra de Maricá (Rocha \& Vrcibradic, 1996), and in other populations of congeners in Brazil (Rocha \& Vrcibradic, 1996; Vrcibradic \& Rocha, 1998); this may be an artifact of the small sample size, since the value of $\mathrm{p}(0.048)$ is very close to the minimum value (0.05) required for considering such a difference as significant, and thus a type II error may have been incurred.

Most of the differences in body temperature among species studied may be due to differences in foraging rates, since wide active foragers tend to be active at higher body temperatures than other lizards.

We conclude that, in the present study, times of activity reflected reasonably well active body temperatures of the lizards (see Bowker, 1984), which in turn are known to be strongly linked to philogeny (e.g. Cooper, 1994). We cannot tell, however, if the differential use of the time niche among the lizard species may reduce interspecific competition in the area. Restingas usually have more depauperate lizard faunas than other habitats in Brazil (see Vitt, 1991, 1995; Vitt \& Zani, 1998), which appears to be due to its recency of colonization (Rocha, 2000). Thus, it is possible that such habitats are not yet "saturated" with species and therefore interspecific competition may not be very intense.

Acknowledgments - This study is a portion of the results of the "Programa de Ecologia, Conservação e Manejo de Ecossistemas do Sudeste Brasileiro" and of the Southeastern Brazilian Vertebrate Ecology Project (Laboratory of Vertebrate Ecology), both of the Setor de Ecologia, Instituto de Biologia, Universidade do Estado do Rio de Janeiro. We thank F. A. Esteves for logistic facilities at the Núcleo de Pesquisas de Macaé (Nupem) during our fieldwork. The study was partially supported by research grants from the Fundação de Amparo à Pesquisa do Estado do Rio de Janeiro - Faperj (processes E26/170.385/97 - APQ1) and from the Conselho Nacional de Desenvolvimento Científico e Tecnológico - CNPq (process 400115/97-2 and 461970/2000-7) to CFDR and also by fellow- 
ships from CNPq to C. F. D. R. (process \# 300819/94-3), M. V. S. (process \# 301117/95-0), and graduate fellowships from the Coordenação de Aperfeiçoamento de Pessoal de Nível Superior - Capes to F. H. H. (process \# 9900369) and from CNPq to D. V. (process \# 143607/98-7), and M. C. B. (process \# 143490/98-2).

\section{REFERENCES}

ARAÚJO, A. F. B., 1984, Padrões de divisão de recursos em uma comunidade de lagartos de restinga, pp. 327-342. In: L. D. Lacerda, D. S. D. Araújo, R. Cerqueira \& B. Turcq (eds.), Restingas: Origem, Estrutura, Processos. Centro Editorial da UFF, Niterói, RJ.

ARAÚJO, D. S. D., SCARANO, F. R., SÁ, C. F. C., KURTZ, B. C., ZALUAR, H. L. T., MONTEZUMA, R. C. M. \& OLIVEIRA, R. C., 1998, Comunidades vegetais do Parque Nacional da Restinga de Jurubatiba, pp. 39-62. In: F. A. Esteves (ed.), Ecologia das Lagoas Costeiras do Parque Nacional de Jurubatiba e do Município de Macaé, RJ. Nupem, Macaé.

BERGALLO, H. G. \& ROCHA, C. F. D., 1993, Activity patterns and body temperatures of two sympatric lizards (Tropidurus torquatus and Cnemidophorus ocellifer) with different foraging tatics in Southeastern Brazil. AmphibiaReptilia, 14: 312-315.

BERGALlO, H. G. \& ROCHA, C. F. D., 1994, Spacial and trophic niche differentiation in two sympatric lizards (Tropidurus torquatus and Cnemidophorus ocellifer) with different foraging tactics. Austr. J. Ecol., 19: 72-75.

BOWKER, R. G., 1984, Precision of thermoregulation of some African lizards. Physiol. Zool., 57: 401-412.

BOWKER, R. G., DAMSCHRODER, S., SWEET, A. M. \& ANDERSON, D. K., 1986, Thermoregulatory behavior of the North American lizards Cnemidophorus velox and Sceloporus undulatus. Amphibia-Reptilia, 7: 335-346.

COLLI, G. R. \& PAIVA, M. S., 1997, Estratégias de forrageamento e termorregulação em lagartos do cerrado e savanas amazônicas, pp. 224-231. In: L. L. Leite \& C. H. Saito (eds.), Contribuição ao Conhecimento Ecológico do Cerrado - Trabalhos selecionados do III Congresso de Ecologia do Brasil. Universidade de Brasília, Brasília, DF.

COOPER, W. E., 1994, Prey chemical discrimination, foraging mode, and phylogeny, pp. 95-116. In: L. J. Vitt \& E. R. Pianka (eds.), Lizard Ecology: Historical and Experimental Perspectives. Princeton University Press, New Jersey.

HENRIQUES, R. P. B., ARAÚJO, D. S. D. \& HAY, J. D., 1986, Descrição e classificação dos tipos de vegetação da restinga de Carapebus, Rio de Janeiro. Rev. Brasil. Bot., 9: $173-189$.

MARTÍN, J. \& LÓPEZ, P., 1996, Avian predation on a large lizard (Lacerta lepida) found at low population densities in Mediterranean habitats: an anlysis of bird diets. Copeia, 1996: 722-726

PIANKA, E. R., 1973, The structure of lizard communities. Ann. Rev. Ecol. Syst., 4: 53-74.
PIANKA, E. R., 1977, Reptilian species diversity, pp. 1-34. In: C. Gans \& D. W. Tinkle (eds.), Biology of the Reptilia. Academic Press.

PIANKA, E. R., HUEY, R. B. \& LAWLOR, L. R., 1979, Niche segregation in desert lizards, pp. 67-115. In: D. J. Horn, R. Mitchell \& G. R. Stairs (eds.), Analysis of Ecological Systems. University Press, Ohio State.

ROCHA, C. F. D., 2000, Biogeografia de répteis de restinga, pp. 99-116. In: L. D. Lacerda \& F. A. Esteves (eds.), Ecologia de Restingas e Lagoas Costeiras. NUPEM/ UFRJ, Macaé, RJ.

ROCHA, C. F. D. \& BERGALLO, H. G., 1997, Intercommunity variation in the distribution of abundance of dominant lizard species in restinga habitats. Ciência e Cultura, 49: $269-274$.

ROCHA, C. F. D. \& VRCIBRADIC, D., 1996, Thermal biology of two sympatric skinks (Mabuya macrorhyncha and Mabuya agilis) in a Brazilian restinga habitat. Austr. J. Ecol., 21: 110-113.

SUGUIO, K. \& TESSLER, M. G., 1984, Planícies de cordões litorâneos quaternários do Brasil: origem e nomenclatura, pp. 15-25. In: L. D. Lacerda, D. S. D. Araújo, R. Cerqueira \& B. Turcq (eds.), Restingas: Origem, Estrutura, Processos. Centro Editorial da UFF, Niterói, RJ.

TEIXEIRA-FILHO, P., RIBAS, S. \& ROCHA, C. F. D., 1995, Aspectos da ecologia termal e uso do habitat por Cnemidophorus ocellifer (Sauria, Teiidae) na restinga da Barra de Maricá, RJ, pp. 155-165. In: F. A. Esteves (ed.), Oecologia Brasiliensis v. 1: Estrutura, Funcionamento e Manejo de Ecossistemas Brasileiros. Instituto de Biologia da UFRJ, Rio de Janeiro.

TEIXEIRA-FILHO, P., ROCHA, C. F. D. \& RIBAS, S., 1996, Ecologia termal e uso do habitat por Tropidurus torquatus (Sauria: Tropiduridae) em uma área de restinga do sudeste do Brasil, pp. 255-267. In: J. E. Péfaur (ed.), Herpetologia Neotropical, Actas del II Congreso Latinoamericano de Herpetologia, II Volumen. Consejo de Publicaciones, Universidad de Los Andes, Merida, Venezuela.

VAN SLUYS, M., 1992, Aspectos da ecologia do lagarto Tropidurus itambere (Iguanidae) em uma área do sudeste do Brasil. Rev. Brasil. Biol., 52: 181-185.

VAN SLUYS, M. \& ROCHA, C. F. D., 1999, Tupinambis merianae (Common tegu): activity. Herpetol. Rev., 30: 4243.

VITT, L. J., 1991, An introduction to the ecology of Cerrado lizards. J. Herpetol., 25: 79-90.

VITT, L. J., 1993, Ecology of isolated open formation Tropidurus (Reptilia: Tropiduridae) in Amazonian lowland rain forest. Can. J. Zool., 71: 2370-2390.

VITT, L. J., 1995, The ecology of tropical lizards in the caatinga of northeast Brazil. Occ. Pap. Oklahoma Mus. Nat. Hist., 1: 1-29.

VITT, L. J. \& CARVALHO, C. M., 1995, Niche partitioning in a tropical wet season: lizards in the Lavrado area of northern Brazil. Copeia, 1995: 305-329. 
VITT, L. J. \& ZANI, P. A., 1998, Ecological relationships among sympatric lizards in a transitional forest in the Amazon of Brazil. J. Trop. Ecol., 14: 63-86.

VITT, L. J., ZANI, P. A. \& CALDWELL, J. P., 1996, Behavioral ecology of Tropidurus hispidus on isolated rock outcrops in Amazonia. J. Trop. Ecol, 12: 81-101.

VITT, L. J., ZANI, P. A., CALDWELL, J. P., ARAÚJO, M. C. \& MAGNUSSON, W. E., 1997a, Ecology of whiptail lizards (Cnemidophorus) in the Amazon region of Brazil. Copeia, 1997: 745-757.

VITT, L. J., ZANI, P. A. \& MARINHO-LIMA, A. C., 1997b, Heliotherms in tropical rain forest: the ecology of Kentropyx calcarata (Teiidae) and Mabuya nigropunctata (Scincidae) in the Curuá-Una of Brazil. J. Trop. Ecol., 13: $199-220$.
VRCIBRADIC, D. \& ROCHA, C. F. D., 1995, Ecological observations on the scincid lizard Mabuya agilis in a Brazilian restinga habitat. Herpetol. Rev., 26: 129-131.

VRCIBRADIC, D. \& ROCHA, C. F. D., 1996, Ecological differences in tropical sympatric skinks (Mabuya macrorhyncha and Mabuya agilis) in South-eastern Brazil. J. Herpetol., 30: 60-67.

VRCIBRADIC, D. \& ROCHA, C. F. D., 1998, Ecology of the Skink Mabuya frenata in an Area of Rock Outcrops in South-eastern Brazil. J. Herpetol., 32: 229-237.

ZAR, J. H., 1984, Biostatistical Analysis. Prentice-Hall, Englewood Cliffs, New Jersey. 